\title{
Correction to: Mutant glucocorticoid receptor binding elements on the interleukin-6 promoter regulate dexamethasone effects
}

Wen-Teng Chang ${ }^{1}$, Ming-Yuan Hong ${ }^{2}$, Chien-Liang Chen ${ }^{3}$, Chi-Yuan Hwang ${ }^{2}$, Cheng-Chieh Tsai ${ }^{4}$ and Chia-Chang Chuang ${ }^{2^{*}}$

\section{Correction to: BMC Immunol 22, 24 (2021)}

DOI: $10.1186 / \mathrm{s} 12865-021-00413-\mathrm{z}$

In this article [1] in the Ethics approval and consent to participate section the IRB was incorrectly given as (IRB No: B-ER-102-121 to CCC). but should have been (IRB No: A-ER-102-200 to CCC). The original article has been updated.

\footnotetext{
Author details

'Department of Biological Science and Technology, Chung Hwa University of Medical Technology, Tainan 701, Taiwan. ${ }^{2}$ Department of Emergency Medicine, National Cheng Kung University Hospital, College of Medicine, National Cheng Kung University, Tainan, Taiwan. ${ }^{3}$ Department of Physical Therapy, I-Shou University, Kaohsiung, Taiwan. ${ }^{4}$ Department of Nursing,
} Chung Hwa University of Medical Technology, Tainan 701, Taiwan.

Published online: 12 July 2021

\section{Reference}

1. Chang WT, et al. Mutant glucocorticoid receptor binding elements on the interleukin-6 promoter regulate dexamethasone effects. BMC Immunol. 2021;22:24. https://doi.org/10.1186/s12865-021-00413-z.

\footnotetext{
The original article can be found online at https://doi.org/10.1186/s12865021-00413-z

* Correspondence: chuanger@mail.ncku.edu.tw

2 Department of Emergency Medicine, National Cheng Kung University Hospital, College of Medicine, National Cheng Kung University, Tainan, Taiwan

Full list of author information is available at the end of the article

(c) The Author(s). 2021 Open Access This article is licensed under a Creative Commons Attribution 4.0 International License, which permits use, sharing, adaptation, distribution and reproduction in any medium or format, as long as you give appropriate credit to the original author(s) and the source, provide a link to the Creative Commons licence, and indicate if changes were made. The images or other third party material in this article are included in the article's Creative Commons licence, unless indicated otherwise in a credit line to the material. If material is not included in the article's Creative Commons licence and your intended use is not permitted by statutory regulation or exceeds the permitted use, you will need to obtain permission directly from the copyright holder. To view a copy of this licence, visit http://creativecommons.org/licenses/by/4.0/. The Creative Commons Public Domain Dedication waiver (http://creativecommons.org/publicdomain/zero/1.0/) applies to the data made available in this article, unless otherwise stated in a credit line to the data.
} 